\title{
O CICLO DA CANA DE AÇÚCAR NO RIO GRANDE DO NORTE (*).
}

O ciclo da cana de açúcar insinuou-se no Rio Grande do Norte nos começos do século XVII pela estrada de Mamanguape, via das comunicações históricas com as capitanias de Itamaracá e Pernambuco: o caminho por onde regressou Mascarenhas Homem, o fundador do forte dos Reis Magos, e por onde desceu rumo à $\mathrm{Ba}$ hia a gente de Luís Barbalho Bezerra. De Olinda para o norte dilatara-se a colonização açucareira estabelecendo-se nas aluviões recentes dos vales costeiros e deixando entre êstes, na superfície pliocênica em que se entalham "os vazios dos tabuleiros como fronteiras mortas" (1).

Insinuou-se tìmidamente, porém, no Rio Grande do Norte, tolhido pelo progressivo agravamento das condições climáticas segundo a latitude e pela rarefação daqueles solos quaternários úmidos que the permitiram rápida eclosão em Pernambuco. De sorte que até meados de oitocentos os engenhos não desempenhariam ali um papel econômico e social realmente importante; em número restrito, permaneceram confinados a algumas das pequenas várzeas meridonais da zona Litoral-e-Mata, tanto que o Ceará Mirim, malgrado suas privilegiadas condições naturais para o cultivo da cana, viu retardar-se de dois séculos e meio o surto agro-industrial canavieiro.

E' certo que se retardou também porque os rebanhos cêdo passaram a concorrer vantajosamente com o açúcar, sobretudo durante a ocupação holandesa. A pecuária dominou desde então tôda a vida colonial norte rio-grandense, com populações de vaqueiros e de pequenos agricultores aplicados a mera lavouras de subsistência nos cursos inferiores da drenagem oriental. As modestas exigências do criatório no tocante à utilização de braços poupou o Rio Grande da condição de mercado negreiro. Os escravos compravam-se em Pernambuco e nenhum foi importado da África (2).

(*). - o presente trabalho, que a Revista de História reproduz com a devida autorização de seu autor, é parte dum relatório apresentado ao Instituto Joaquim Nabuco de Pesquisas Sociais, do Recife, sôbre "Os rios do açúcar do Nordeste" (Nota da Redação).

(1). - Mário Lacerda de Melo, Livret-Guide, n.0 7, pg. 82. Union Geographique Internationale, Rio, 1956.

(2) . - Luís da Câmara Cascudo, História do Rio Grande do Notte, pg. 46. Rio, 1955. 
A participação do elemento negro na população colonial foi, assim, sensivelmente reduzida. Além disso, como vaqueiro, o prêto campeador das fazendas de gado, trotando ao lado do senhor ou do filho do senhor e com êles vestindo, aboiando e acampando, realizou-se como uma constante assaz diversa do prêto dos canaviais ou da mineração:

"solto pelo lado de dentro, violeiro, sambador, ganhando dinheiro, alforriando-se com a viola, obtendo terras para criar junto ao amo, seu futuro compadre" (3).

Mesmo nos vales afinal densamente povoados do Ceará Mirim e de São José do Mipibu, onde os primeiros engenhos chegaram a ser fundados bem antes da abolição e onde o contingente africano foi mais numeroso ou menos ralo do que noutras partes do Rio Grande do Norte, o prêto dissipou-se na fácil mestiçagem. Em 1854 a Bahia tinha mais de 58 escravos por engenho e o Rio Grande do Norte menos de 11 . Ou, como preferiu dizê-lo o presidente Antônio Bernardo Passos, havia na Bahia oito vêzes mais engenhos e quarenta seis vêzes mais escravos.

A campanha abolicionista fêz-se em condições de acentuada receptividade e o 13 de maio encontrou apenas 482 negros ainda não alforriados; que alforriados vinham sendo, aliás, costumeiramente desde muito na pia batismal pelos padrinhos brancos ou nas disposições testamentárias (4). A abolição, de resto, seguiu-se de perto aos primeiros momentos da aristocracia rural açucareira do Ceará Mirim, onde a viúva do primeiro barão-do-açúcar norte-riograndense, D. Bernarda Varela Dantas, antecipara-se à emancipação.

Esse considerável compasso de espera do ciclo açucareiro e do patriarcado rural dos senhores de engenho explica-se principalmente pela inexistência, no vale fertil do Ceará Mirim, de condições adequiadas à instalação de engenhos d'água. $\mathrm{Na}$ porção meridional das zonas Litoral-e-Mata e Agreste do Rio Grande do Norte, onde a fachada atlântica do planalto está sob totais pluviométricos mencs escassos e menos mal distribuídos do que os reinantes nos chatos sertões que cingem a projeção setentrional da Borborema, os formadores do Potengí, Trairí, Jacú e Curimataú têm um regime ainda irregular, é certo, porém, sensivelmente atenuado em relação ao Ceará Mirim; e uma descarga, portanto, algo mais concentrada ou algo menos difusa. O decisivo, porém, é que o flanco oriental do planaito, onde êles nascem, é afetado pelo tectonismo da "flexura" continental. Donde os sinais de rejuvenescimento mais enfático que ocorrem nos cursos meridionais do Rio Grande do Norte e a

(3). - Ibidem, pg. 45 .

(4). - Ibidem, pg. 187. 
existência neles, perto do litoral, de gradientes suscetiveis de permitir a instalação de rodas d'água. Onde êsses gradientes coincidiram com várzeas úmidas quaternárias surgiram os banguês. Assim o mais antigo estabeleceu-se no baixo curso do Curimataú, a várzea do Cunhaú, que é hoje a mais meridional das várzeas úmidas do Estado. Em 1630, nos têrmos da informação do espião Verdonck, fabricava o engenho Cunhaú seis a sete mil arrôbas anuais, que se exportavam por mar para Pernambuco juntamente com mi1ho, farinha e gado. Outros engenhos houve em três das sete várzeas descritas em 1607 pela Relação das Cousas do Rio Grande, do sítio e disposição da terra: as do Camaratuba (hoje em território paraibano), do Curimataú e do Jundiaí. E cultura da cana em tôdas sete, inclusive na do Ceará Mirim, a respeito da qual se faz a primeira menção histórica sôbre a possibilidade de se instalarem engenhos:

\footnotetext{
"tem de comprido cinco ou seis léguas; tôda ela terra para engenhos, tem cana de açúcar muito formosa, e nela os indios fazem grandes lavouras no verão. Grã parte des. ta várzea é da Companhia de Jesus" (5).
}

Nada obstante a fama do Ceará Mirim remontava ao tempo das tentativas pioneiras de conquista e povoamento. Foi na embocadura do Baquipe, ou rio Pequeno (depois Ceará Mirim) que os filhos de João de Barros, vindos do Maranhão após a morte do parceiro do pai, Aires da Cunha, encontraram os franceses mancomunados com a indiada no comércio clandestino do pau-brasil. Isso aconteceu aí por 1535 ou 1536: antes portanto, de fundar-se a cidade do Natal do Rio Grande, nos fins do mesmo século. A expedição foi repelida. Se vitoriosa, sugere Cascudo (6), seguindo-se o povoamento português do vale, talvez o Rio Grande do Norte se tivesse chamado Ceará, antecipando-se ao batismo da capitania dêsse nome. Porque mirim só se chamou depois, para diferenciar do Ceará Grande.

Mesmo sem engenhos de açúcar, o vale do Ceará Mirim veio a ser, na éra colonial, o conduto de mais intensa penetração do território. O povoamento começara no litoral, entre Pôrto Mirim e Muriú (7) internando-se depois pelas margens da lagoa de Estremoz com roças e criatório. A lavoura de cana, porém, referida pela Relação indica que em 1604 progredira vale acima. Um documento de dez anos depois registra o avanço da colonização até Itapiabá,

\footnotetext{
(5). - Pe. Serafim Leite, História da Comprinhia de Jesus no Brasil, I, pg. 557. Lisboa-Rio, 1938.

(6). - Luís da Câmara Cascudo, op. cit., pgs. 5 e 17.

(7). - Ibidem, pg. 57.
} 
hoje Taipú, já no Agreste. Aí deteve-se durante um século, como pôsto avançado mais remoto da criação colonial.

Porque o negócio do gado, que experimentara particulares estímulos no tempo dos holandeses, definiu-se como atividade econômica dominante mesmo no vale do Ceará Mirim, onde André Vidal de Negreiros mandava em 1647 arrebanhar cabeças para abastecimento dos restauradores de Pernambuco. Isso apesar de que chegara a haver um propósito oficial de exploração açucareira do vale: foi a incumbência feita pelo governador de Pernambuco, Alexandre de Moura, ao "mestre de engenhos da Paraíba", Jerônimo Mateus, e a dois moradores do Rio Grande, de correrem

"as terras duma e doutra banda do rio na várzea do Seara, assim as que houver ao redor dela, para declararem muito particularmente se nelas há terras para canas e para se poder fazer algum engenho de açúcar d'água ou trapiche" (8).

Já então (1614) das 186 datas de terra repartidas no Rio Grande cêtca de 23 distribuiam-se no vale entre portuguêses pescadores e fazendeiros de gado, estando provàvelmente algumas delas compreendidas nas 14 léguas doadas pelo capitão-mor Jerônimo de Albuquerque aos padres jesuítas. O relatório do "mestre de engenhos" informou que a terra era boa para o plantia de cana xuta),

"na parte dela que está desalagada" (a várzea en-

mas que para engenho d'água, embora houvesse água bastante, seria necessário subir o rio ao
"nascimento e tirar-lhe o nivel para se potler saber ao certo se tinha altura para engenho".

Seria possivel fazer "mais de dois trapiches", de resto, contanto que se drenasse o "alagadiço"; mas a drenagem dependia da corrente que se pudesse ir buscar a montante.

A esperança de mestre Jerônimo Mateus não tinha fundamento. A "água bastante" da planície de inundação do Ceará Mirim não tem sua perenidade assegurada pelas enchentes anuais que, além de muito breves e torrenciais, às vêzes até faltam. A extrema irregularidade do regime corta o curso, no estio, dentro mesmo da várzea enxarcada. O vale úmido é obra do rio, mas não porque êste o umidifique, e sim porque se construiu de maneira a se assegurar de quase inteira autonomia. São os drenos suplementares, alimentados pelos "olheiros" da base das vertentes e dos "pauis" do "alagadiço", que suprem a várzea d'água durante todo o ano. Além dis-

(8). - Luís da Câmara Cascudo, Histótia do Ceará Mirim (inédito). 
so, a obstrução da antiga "ria" pelas areias litorâneas concorre para que a água se detenha e armazene nos sedimentos da dilatada calha em mangedoura. O lençol hidrostático permanece, dessarte, à flor da terra quase, e há de ser alimentado sobretudo pela drenagem subterrânea que se faz através dos horizontes calcáreos da base das barreiras em que se aprofundou o vale epigênicamente. Nenhuma correnteza, portanto, aí ocorre capaz de mover a roda d'água dum engenho "baixeiro", quanto mais de "meieiros", ou "copeiros", se usarmos a nomenclatura por que, em Pernambuco, se classificavam os antigos banguês conforme a água thes impulsionasse a roda apanhando-a por cima, na altura do eixo, ou tangente por baixo.

Os problemas morfológicos e hidrológicos, porém, já foram sugeridos a seu tempo. O que importa aqui é que a encomenda feita ao "mestre de engenhos" não o incumbira de opinar sôbre a construção de almanjarras, e Jerônimo Mateus não opinou. O Ceará Mirim jamais viria a ter engenhos d'água, e foi êsse o handicap que diferiu, na várzea, a introdução do ciclo. Os primeiros montados, aí por 1845 , eram de tração animal, mas o registro de seu aparecimento não tem apenas interêsse cronológico, pois a ênfase econômica da agro-indústria no vale já se começa a acentuar antes de 1865; o ano das primeiras moendas horizontais no vale movidas a vapor.

Eram já frequientes, com efeito, desde aquele tempo das toscas almanjarras e a despeito delas, os registros acêrca da florescente povoação que se adensava ao redor do "olheiro" da Bôca da Mata, embrião da futura Ceará Mirim. O cultivo da cana para as engenhocas movidas à fôrça de bestas ocupava a maior parte da população em que ao elemento português, diligente e pioneiro, acrescentavam-se por emulação, naturais do país, inclusive numerosos mestiços, todos muito empenhados no aproveitamento do vale. Provàvelmente as grandes sêcas sertanejas cíclicas contribuiram para a concentração demográfica; tal como aconteceu quando da de 1877, ano em que começou a ser povoado e explorado o vale do Maxaranguape, até então inculto e mesmo deserto. Os "alagadiços" do Ceará Mirim não eram bem-de-família, ninguém os disputara dantes como principal espólio hereditário; de sorte que o massapê da várzea se oferecia às iniciativas quase como res nullius. Daí a rapidez com que as terras férteis foram repartidas e exploradas. Em 1847 as seis ou sete mil arrôbas do solitário Cunhaú de 1614 subiam a quatrocentas mil no Rio Grande; e a maior parte fabricava-se nos engenhos da Bôca da Mata, daí saindo em tropas para o interior e para o norte da província, onde funcionava como moeda ou se trocava por sal nos entrepostos. Cêdo o Rio Grande do Norte deixaria de importar açúcar de Pernambuco. 
Cêdo também, as rivalidades entre a vila de Estremoz, cabeça da comarca, e a Bôca da Mata tiveram ruidoso desfêcho com a trans ferência, em 1855, da sede para a povoação enfàticamente crismada de "briosa vila do Ceará Mirim". Os ciúmes, contudo, da vetusta Estremoz, ciosa de suas tradições seculares que recuavam ao aldeiamento jesuítico de São Miguel de Guajirú, eram recalcitrantes, e a mudança da sede só se fêz definitiva anos depois, quando afinal o surto de prosperidade material do Ceará Mirim falou mais alto e mais categòricamente do que velhos privilégios abstratos.

O climax do patriarcado rural ocorreria em breve, com a multiplicação dos engenhos a vapor e a construção da estrada de ferro, mas a progressão do ciclo nunca se fêz constante, vacilando freqüentemente por efeito da concorrência do algodão e dos derradeiros esforços de reanimação da pecuária. No quadro geral da receita dos municípios potiguares entre 1894 e 1910 o Ceará Mirim figura em quinto lugar. Nesse interregno instalou-se o primeiro vácuo para a produção do açúcar branco no engenho São Francisco e o vale fabricava $60 \%$ do açúcar de todo o Rio Grande. Ainda no primeiro quartel dêste século surgiu a primeira usina, a Guanabara, que não perseverou . Em 1942' havia duas no Ceará Mirim e uma em Arez, no rio Jacu. A mais recente é a Santa Terezinha, instalada em 1948.

A usina Estivas, no Jacú, fabrica atualmente 70.000 sacos anuais e mói canas, também das várzeas do Cunhaú, Ururarí e Trairí, havendo nesses vales engenhos "de fogo acêso" e fábricas de rapadura. Com engenhos de rapadura há ainda, no município de Touros, nada menos de 11 vales úmidos, dos quais o mais importante é o do Maxaranguape; mesmo neste, contudo, a cana é cultivada com adubos, pois lá não se repete a fertilidade natural dos solos do Ceará Mirim, cujas usinas, de resto, absorvem a maior parte das colheitas do Maxaranguape.

A mais nova aristocracia rural da história do açúcar do Nordeste brilhou por pouco tempo. Teve seus dias de fastígio, como Goiana, Nazaré, Mamanguape, mas que não foram muito além de meio século. Famosas ficaram as festas dos engenhos, notadamente as do engenho Guaporé. Onde as modas européias de primeira mão pavoneavam-se à revelia inteira de Natal. Ainda há sobradões, no centro urbano, que testemunham a hora de esplendor; e dentre as numerosas casas-grandes de engenhos do vale sobressai o sobrado do primeiro barão do Ceará Mirim, Francisco Varela do Nascimento, construído exatamente há cem anos passados ao lado da almanjarra, e conservado ainda na "várzea enxuta" onde se levantou a usina São Francisco. 
A "botada" dos engenhos chegou a ser quase tão célebre quanto as de Pernambuco e Paraíba. A tradição guarda-se hoje ainda na usina São Francisco, cujo edifício conserva, como uma dependência, os restos do antigo engenho do mesmo nome: missa, invocação de Nossa Senhora da Conceição, almôço oferecido às famílias dos proprietários vizinhos, bênção e banda de música. Mais costumeira, porém, do que essa antiga festa de suficiência do patriarcado rural açucareiro, vai-se fazendo a de ação de graças, no fim da moagem. Atento à contabilidade, o capital celebra a safra na medida em que esta mais rendeu; distribuem-se gratificações conforme o rendimento, matam-se bois e fazem-se "bailes" populares.

Algumas das linhagens da nobreza rural do açúcar no Ceará Mirim - os Varela, os Carrilho, os Leopoldo, os Pereira, os Câmara, os Dantas - deram ao Império e à República vários nomes falados. Não apenas políticos; deram também médicos, localmente famosos, bacharéis, magistrados e homens de letras que hoje se projetam fora do Rio Grande. Da casa grande da usina Ilha Bela, alçada panorâmicamente no meio do vale, avistam-se, em redor, três engenhos ilustres: em cada um dêles nasceram o professor Nilo Pereira, o historiador Rodolfo Garcia e o escritor Jaime Adour da Câmara.

GILBERTO OSORIO DE ANDRADE

(da Universidade do Recife). 